\title{
Zaginięcia kryminalne, czyli szukanie śladów po latach
}

\author{
JOANNA StOJER-PolańSKA
}

ORCID: 0000-0001-5599-2527

Wydział Psychologii Uniwersytetu Humanistycznospołecznego SWPS w Katowicach

Kryminalistyka jest nauką, która zajmuje się badaniem śladów, ich identyfikacją i indywidualizacją. Aby te różnego rodzaju ślady mogły być zbadane, muszą najpierw zostać ujawnione i zabezpieczone. Pierwszą trudnością przy poszukiwaniu osób zaginionych jest ustalenie miejsca, w którym ślady powinny być ujawnione. Chodzi o ślady związane z człowiekiem, jego ostatnim miejscem pobytu, miejscem, gdzie mogło dojść do popełnienia czynu zabronionego, albo też miejscem ukrycia śladów po popełnieniu czynu. Mogą to być ślady bytności zaginionego, a także ślady działań osób trzecich, związanych również z działaniami po popełnieniu czynu przeciwko życiu zaginionego, np. z ukryciem śladów lub pozoracją innego zdarzenia. W świecie kryminalistyków powszechnie wiadomo, że nie istnieje ,zbrodnia doskonała”, wciąż jednak wiele spraw pozostaje nierozwiązanych. Sprawy zabójstw, które początkowo są zaginięciami, czasami czekają wiele lat na ujawnienie, wykrycie i ewentualne osądzenie sprawcy.

Oględziny w przypadku zgłoszenia zaginięcia mogą być prowadzone dopiero w momencie, kiedy można ustalić, w którym miejscu podejrzewamy popełnienie czynu zabronionego bądź też ujawnienie śladów związanych z popełnionym czynem zabronionym. Zdarzają się sytuacje, kiedy najpierw prowadzone są poszukiwania celem odnalezienia właści- 
wego miejsca lub zostaje ono ujawnione przypadkowo. Czynność procesową, jaką są oględziny, można prowadzić dopiero po ustaleniu, przynajmniej wstępnym, okoliczności i miejsca zdarzenia. Miejsce to często jednak nie jest znane albo nie wiadomo, jakich śladów należy się w danym miejscu spodziewać. Na tym etapie zakładane są często różne wersje śledcze i nie wiadomo, która będzie miała potwierdzenie w śladach.

Zaginięcie kryminalne, jako osobne pojęcie, nie jest zdefiniowane $\mathrm{w}$ zarządzeniu, które reguluje kwestię prowadzenia poszukiwań ${ }^{1}$. Jako zaginięcie przepisy cytowanego zarządzenia przyjmują ,zaistnienie zdarzenia, uniemożliwiającego ustalenie miejsca pobytu osoby fizycznej, wymagające jej odnalezienia albo udzielenia pomocy w celu zapewnienia ochrony życia, zdrowia lub wolności”. Zaginięcie może być więc spowodowane przestępstwem. Osoba zaginiona może być ofiarą przestępstwa przeciwko życiu, zdrowiu i wolności, a także przestępstwa przeciwko innym dobrom prawnym, jak wolność czy wolność seksualna, które skutkują zaginięciem, czyli sprawca doprowadza do tego, że nie można odnaleźć osoby zaginionej.

Przepisy wprowadzają także pojęcie kategorii poszukiwań i do nich również można odnieść pojęcie ,zaginięcia kryminalnego”. Poziom poszukiwań zdefiniowano we wspomnianym zarządzeniu jako

stopień określający niezwłoczność i zakres podjęcia czynności poszukiwawczych w zależności od stwierdzonego ryzyka wystąpienia zagrożenia dla życia, zdrowia lub wolności osoby zaginionej, oznaczony jako:

a) poziom I - dotyczący osoby, której zaginięcie związane jest $\mathrm{z}$ realnym, bezpośrednim występowaniem zagrożenia dla jej życia, zdrowia lub wolności, dla którego ratowania wymagane jest bezpośrednie i natychmiastowe podjęcie czynności poszukiwawczych z zaangażowaniem znacznych sił i środków ze strony Policji, na przykład dotyczące osoby:

- małoletniej w wieku do 10 lat,

— małoletniej w wieku od 11 do 13 lat, zaginionej po raz pierwszy,

— niezdolnej do samodzielnej egzystencji,

— wymagającej stałego przyjmowania leków, których brak przyjęcia w odpowiednim czasie stanowi zagrożenie jej życia,

${ }^{1}$ Zarządzenie nr 48 Komendanta Głównego Policji z dnia 28 czerwca 2018 roku w sprawie prowadzenia przez Policję poszukiwania osoby zaginionej oraz postępowania w przypadku ujawnienia osoby o nieustalonej tożsamości lub znalezienia nieznanych zwłok oraz szczątków ludzkich (Dziennik Urzędowy Komendy Głównej Policji 2018, poz. 77). 
— zaginionej w związku z realnym podejrzeniem popełnienia na jej szkodę przestępstwa przeciwko życiu lub wolności,

- której zachowanie w realny sposób wskazywało na bezpośredni zamiar popełnienia samobójstwa, a natychmiastowe podjęcie czynności poszukiwawczych oraz zaangażowanie znacznych sił i środków z dużym prawdopodobieństwem przyczyni się do zapobieżenia zamachu samobójczego,

— zaginionej w warunkach atmosferycznych zagrażających jej życiu w przypadku niezwłocznego nieodnalezienia;

b) poziom II — dotyczący osoby, której zaginięcie związane jest z uzasadnionym podejrzeniem wystąpienia ryzyka zagrożenia dla jej życia, zdrowia lub wolności, na przykład dotyczące osoby:

— deklarującej po raz kolejny zamiar popełnienia samobójstwa, albo której deklaracja zamiaru popełnienia samobójstwa nie stanowiła realnych przesłanek jej spełnienia,

— małoletniej w wieku od 14 do 18 lat zaginionej po raz pierwszy,

— zdolnej do samodzielnej egzystencji, ale wymagającej opieki i stałego przyjmowania leków, których nieprzyjęcie może spowodować zagrożenie jej zdrowia,

— zaginionej za granicą Rzeczypospolitej Polskiej, wobec której istnieje uzasadniona potrzeba udzielenia pomocy w celu ochrony jej życia, zdrowia lub wolności;

c) poziom III - dotyczący osoby, której zaginięcie nie jest związane z bezpośrednim oraz uzasadnionym zagrożeniem dla jej życia, zdrowia lub wolności, na przykład dotyczące osoby:

— wyrażającej wolę zerwania kontaktów z rodziną, osobami najbliższymi lub środowiskiem, w którym ostatnio przebywała,

— która oddaliła się z miejsca zamieszkania w wyniku nieporozumień rodzinnych,

— co do której nie jest możliwe ustalenie przyczyn lub okoliczności zaginięcia,

— z którą brak jest kontaktu, a która deklarowała chęć wyjazdu lub jej zaginięcie związane jest z wyjazdem albo pobytem za granicą Rzeczypospolitej Polskiej,

— niewymagającej stałej opieki medycznej lub stałego przyjmowania leków, która samowolnie oddaliła się z placówki opiekuńczej, leczniczej lub innej placówki,

— małoletniej w wieku od 11 do 13 lat zaginionej po raz kolejny.

Dodatkowo przepisy zdefiniowały także poszukiwanie opiekuńcze i porwanie rodzicielskie. Warto zaznaczyć, że przy zgłoszeniu zaginięcia nie zawsze wiadomo, jaki ma ono charakter. Nie można też założyć, że osoby zgłaszające zaginięcie zawsze podają prawdziwe informacje na temat okoliczności zaginięcia ${ }^{2}$. W sprawach rozwiązanych wielokrotnie okazywało się, iż zgłaszający zaginięcie okazywał się być sprawcą prze-

2 M. Górecki, Ciemna liczba przestępstw - zaginięcie osoby, [w:] Przypadki kryminalne. Poszukiwania osób zaginionych jako problem interdyscyplinarny, red. J. Stojer-Polańska, Poznań 2018, s. 195. 
stępstwa przeciwko życiu zaginionego ${ }^{3}$. Nie ulega jednak wątpliwości, że wiele zgłoszeń zaginięć pochodzi od osób, które naprawdę przejmują się losem osoby zaginionej i dążą do tego, aby osobę tę odnaleźć, choć nie zawsze posiadają wszystkie istotne w sprawie informacje $\mathrm{e}^{4}$. Często okazuje się, że rodzina czy bliscy nie mają wielu ważnych informacji dotyczących chociażby problemów, z którymi borykała się osoba zaginiona ${ }^{5}$. Kluczowe mogą być informacje o problemie wpadnięcia w tzw. spiralę długów, uzależnieniu od hazardu czy prowadzeniu „,podwójnego życia”. Osobom zgłaszającym zaginięcie nie zawsze są znane miejsca szczególnie ważne dla zaginionego, a w takim miejscu mógł on stać się ofiarą przestępstwa.

Przy wprowadzeniu poziomów poszukiwań, a wcześniej kategorii osób zaginionych ${ }^{6}$, zapewne chodziło o to, aby określić, jak intensywne powinny być działania poszukiwawcze i jak szybko należy je podjąć ze względu na ochronę dóbr osoby zaginionej. W szczególności chodzi o życie i zdrowie zaginionych. Zaginięcie kryminalne można zdefiniować jako takie, kiedy zaginięcie spowodowane zostało czynem zabronionym. Często są to sytuacje, kiedy ciało osoby zaginionej zostało ukryte przez sprawcę przestępstwa przeciwko życiu bądź - ale takich przypadków jest mniej — osoba była przetrzymywana w jakimś miejscu bez swojej zgody przez długi czas. Są to sprawy trudne do rozwiązania. Najczęściej dlatego, że sprawca pozoruje pewne czynności i celowo chce utrudnić odnalezienie ${ }^{7}$. To jednak nie oznacza, że nie są to sprawy bez śladów kryminalistycznych.

3 J. Stojer-Polańska et al., Ślady osób zaginionych, [w:] Przypadki kryminalne. Wspótpraca interdyscyplinarna przy badaniu ciemnej liczby przestępstw, red. J. Stojer-Polańska, Poznań 2016, s. 23.

4 S. Kaczan, Zaginięcia kryminalne, [w:] Przypadki kryminalne. Wspólpraca interdyscyplinarna ..., s. 58.

5 R. Diller, M. Puzio-Broda, „Minął już tydzień odkąd zaginęła twoja matka (...)” - historie wymagajace wyjaśnienia, czyli nierozwiązane sprawy zaginięć osób, [w:] Przypadki kryminalne. Ciemna liczba przestęstw jako problem interdyscyplinarny, red. J. Stojer-Polańska, Poznań 2019, s. 30.

6 A. Wentkowska, Poszukiwania osób zaginionych. System i metody działania w procedurach stużb, Warszawa 2016, s. 10.

7 J. Stojer-Polańska, B. Michalec, M. Lisowicz, ,, To be or not to be”. Samobójstwo z perspektywy stużby $w$ Archiwum X, [w:] Percepcja zachowań samobójczych. Między opiniami a doświadczeniami, red. K. Rosa, A. Czabański, Kraków 2014, s. 36. 
Śladem przy zaginięciu może być każda rzecz, informacja czy zachowanie osoby związanej z zaginięciem, a także brak takiej rzeczy, informacji czy też brak danego zachowania. Łatwo można sobie wyobrazić ślady materialne w miejscu zaginięcia, jak ślady krwawe, ślady mechanoskopijne świadczące o dynamicznym zdarzeniu typu szarpanina sprawcy z ofiarą, ślady balistyczne czy ślady wskazujące na użycie innego narzędzia, ślady wskazujące na próbę ukrycia zwłok, np. poprzez rozkawałkowanie ciała bądź też zakopanie go, czy też ślady innej próby ukrycia zdarzenia, jak np. spalenie zwłok czy ukrycie ich pod wodą. Śladem może być także to, co przekaże osoba zgłaszająca zaginięcie, np. informacje fałszywe mające odwrócić uwagę od miejsca, w którym doszło do zaginięcia. Warto zwracać na tego typu szczegóły uwagę, zwłaszcza że w literaturze i praktyce sformułowano przesłanki świadczące o tym, iż w sprawie zaginięcia mogło dojść do zabójstwa ${ }^{8}$. Takim śladem związanym z zachowaniem sprawcy zaginięcia mogą być też tzw. ślady na duszy (określenie funkcjonariuszy krakowskiego Archiwum $X^{9}$ ), np. sprawca zabójstwa od dnia pozbawienia osoby zaginionej życia co noc zostawia zapalone światło ${ }^{10}$, a wcześniej tego nie robił. Opisane zostały w literaturze przypadki, kiedy po wielu latach od dokonania zabójstwa tego typu sprawy zaginięć zostały rozwiązane i potwierdzono na etapie postępowania sądowego, że były faktycznie zabójstwami ${ }^{11}$. Ciągle w toku są takie sprawy, gdzie na poziomie prowadzonych czynności operacyjnych przez policję można typować, co się stało, choć sprawy procesowo nie są zakończone i sąd nie wypowiedział się w sprawie kwalifikacji prawnej zdarzenia ${ }^{12}$. Zdarzają się także sprawy, w których toczą się czynności procesowe, a nawet jest wnoszone oskarżenie o zabójstwo pomimo braku odnalezienia ciała ofiary. Niestety, nie są to częste procesy w realiach polskich. Są oczywiście i takie sytuacje, kiedy sprawy nie są prowadzone procesowo wobec braku wszczę-

${ }^{8}$ R. Diller, M. Puzio-Broda, op. cit.; M. Górecki, op. cit.

9 P. Litka, B. Michalec, M. Nowak, Polskie Archiwum X, Kraków 2016, s. 16; P. Litka, B. Michalec, M. Nowak, Polskie archiwum X. Nie ma zbrodni bez kary, Kraków 2018, s. 27.

10 B. Michalec, D. Piniewska-Róg, J. Stojer-Polańska, Czego oczy nie widza...? Studium pewnego zaginięcia, [w:] Przypadki kryminalne. Ciemna liczba przestępstw przeciwko kobietom, red. J. Stojer-Polańska, Poznań 2019, s. 33.

11 P. Mrozowski, Zte żony i kochajacy mężowie - studium przypadków, [w:] Przypadki kryminalne. Ciemna liczba przestepstw przeciwko kobietom..., s. 36.

12 R. Tracz, Kochać to nie znaczy zawsze to samo, czyli dwie dekady z życia psychopaty, [w:] Przypadki kryminalne. Ciemna liczba przestęstw przeciwko kobietom..., s. 80. 
cia postępowania, pomimo prowadzenia działań w sprawie i powoływania biegłych psychologów w celu stworzenia profilu osoby zaginionej — czy mogła popełnić samobójstwo bądź dokonać ucieczki, czy też mogła paść ofiarą przestępstwa - i te sprawy nie kończą się skazaniem ${ }^{13}$. Być może w przyszłości, w przypadku ujawnienia innych śladów, będzie się toczyć postępowanie przeciwko konkretnej osobie o dokonanie np. zabójstwa czy też innego czynu.

Ślad w postaci braku zachowania może być związany np. z tym, że zaginięcie zostaje zgłoszone dużo później, niż miało miejsce ${ }^{14}$. Zachowanie takie może mieć wiele przyczyn. Sprawca może potrzebować czasu na przygotowanie swojej wersji zdarzenia i dokonanie pozoracji, przygotowanie alibi, podjęcie próby zatarcia śladów. Inna możliwość to taka, kiedy zgłaszający spodziewa się powrotu osoby zaginionej, ta jednak nie wraca. Może tak być w sytuacji, kiedy osoba zaginiona już wcześniej miewała tego typu epizody, ale i wtedy, kiedy osoba zgłaszająca boi się zgłosić zaginięcie, ponieważ osoba zaginiona może jej mieć to za złe. Zaginięcie może być przez jakiś czas niezgłoszone także z powodu prowadzenia przez zaginionego działalności sprzecznej z prawem, kiedy bliscy nie chcą, by te okoliczności zostały przez policję ujawnione. Brak zgłoszenia może też wynikać z tego, że zaginiony bywał agresywny, np. z powodu nadużywania alkoholu, i może się zachować nieobliczalnie w sytuacji, kiedy się dowie, iż zgłoszono jego zaginięcie. Zdarzają się przecież sytuacje, kiedy osoba zaginiona wie o tym, że jest poszukiwana przez rodzinę i policję, ale nie chce kontaktu ani z bliskimi, ani ze służbami mundurowymi.

Powoływane na początku tekstu zarządzenie regulujące kwestię poszukiwań mówi o zabezpieczeniu śladów przy pierwszym poziomie poszukiwań. Zgodnie z nim należy ,zabezpieczyć ujawnione ślady i dowody związane z zaistniałym zdarzeniem, w tym materiał biologiczny umożliwiający oznaczenie profilu DNA osoby zaginionej”. Trudność polega na tym, że często nie wiadomo, jakiego typu ślady i dowody mogą być istotne. Aby zabezpieczyć ślady, można przeprowadzić oględziny. Jest to stosunkowo rzadko wykonywana czynność zaraz po zgłoszeniu związanym z zaginięciem. Często bywa dopiero efektem prowadzonych poszukiwań,

13 E. Wach, Zbrodnie nieidealne, [w:] Przypadki kryminalne. Wspótpraca interdyscyplinarna..., s. 70 .

14 M. Górecki, op. cit. 
a w międzyczasie ślady mogą ulec kontaminacji albo w ogóle nie będzie możliwe ich zabezpieczanie. Zdarzały się takie sprawy, kiedy dopiero po jakimś czasie od zgłoszenia zaginięcia ujawniano ślady krwi, które później zidentyfikowano jako ślady ofiary zaginięcia, ale trudno było już kategorycznie wnioskować na ich podstawie o przebiegu zdarzenia. Nie było zaś wątpliwości, czyje to ślady. Trudności w badaniu śladów ujawnionych długo po zdarzeniu widać w głośnej sprawie zaginięcia kobiety w okolicach rzeki Warty, kiedy ciało dopiero po ośmiu miesiącach zostało poddane badaniom medyczno-sądowym, co nie pozwoliło na ustalenie, czy na ciele znajdują się obrażenia zadane przez osoby trzecie, czy przez okoliczności związane z oddziaływaniem innych czynników.

Śladem może być wszystko. Szansa na zabezpieczenie największej liczby śladów kryminalistycznych jest tylko w krótkim czasie po zaginięciu kryminalnym. Potem jest to zdecydowanie trudniejsze, choć są i takie przypadki, kiedy nawet po wielu latach udaje się zabezpieczyć dużo śladów materialnych związanych ze zdarzeniem. Dużo zależy od charakteru miejsca, w którym doszło do popełnienia przestępstwa i ukrycia ciała osoby zaginionej. Jeśli to miejsce rzadko uczęszczane, śladów może być dużo nawet po wielu latach. Jeśli zaś w miejscu zaginięcia powstaje osiedle mieszkaniowe, o zbadanie śladów będzie dużo trudniej.

Są jednak takie sprawy, kiedy zagadka związana z zaginięciem, pomimo upływu lat, nie zostaje rozwiązania. To dramaty wielu rodzin, które czekają na informację, co się stało. Często do końca mają nadzieję, że osoba zaginiona żyje. Jeśli nadziei już nie mają i zaakceptowali myśl, iż bliski padł ofiarą przestępstwa, oczekują ukarania sprawców. Nie ma spraw beznadziejnych, są jednak takie, które bardzo długo czekają na swoje rozwiązanie. Sformułowanie ,nie ma spraw beznadziejnych” zostało nawet tytułem tekstu o działalności Archiwum X w Polsce ${ }^{15}$. Są to jednostki działające przy komendach wojewódzkich policji, które zajmują się nieujawnionymi wcześniej lub niewykrytymi sprawami przestępstw, w szczególności zabójstw. Te działania są bardzo potrzebne, bo dają szansę na ponowne przyjrzenie się sprawie po latach. W Archiwach $\mathrm{X}$ często działają zaangażowani funkcjonariusze, którzy szukają rozwiązań, wykorzystując nowe możliwości kryminalistyki oraz ponownie ana-

15 E. Sitek, Nie ma spraw beznadziejnych, „Policja 997” 2017, nr 10-11, s. 8. 
lizując motywy zaginięcia, okoliczności zdarzenia, ślady niematerialne. Przyjrzenie się sprawie po latach pozwala na analizę pod innym kątem. Są sprawy, w których krótko po zgłoszeniu zaginięcia możliwe i prawdopodobne wydaje się przyjęcie wersji o ucieczce z domu czy celowym zerwaniu kontaktów. Jednak czasami właśnie upływające lata bez żadnego kontaktu ze strony osób zaginionych powodują, że wersja o tym, iż padły ofiarą przestępstwa, wydaje się dużo bardziej prawdopodobna. Jeśli ktoś latami nie podejmuje pieniędzy ze swojego konta, nie dzwoni do bliskich, nie uruchamia telefonu, nie zamyka rachunku bankowego czy nie wypowiada umowy najmu, nie kontaktuje się ze swoimi dziećmi ani rodzicami, prawdopodobna wydaje się hipoteza zabójstwa.

Zdarza się, że ponowna analiza akt pozwala dostrzec w sprawie coś, co wcześniej zostało przeoczone. Czasami ta okoliczność dopiero po latach jest widoczna. Są takie sprawy, w których dopiero po upływie dłuższego czasu można przyjąć, że osoba nie dokonała ucieczki i nie oddaliła się samowolnie, nie chcąc mieć kontaktu z rodziną. Dlatego znaczenie mają nie tylko działania podejmowane natychmiast po zgłoszeniu zaginięcia, ale również te po wielu latach od zdarzenia. Każde z tych działań powinny być prowadzone przez odrębne wyspecjalizowane komórki policyjne.

Niezwykle istotna jest współpraca wszystkich instytucji, które mogą pomóc przy zaginięciach kryminalnych. Chodzi o działania służb mundurowych, ale również grup poszukiwawczych, wolontariuszy biorących udział w poszukiwaniach oraz o wykorzystanie możliwości technicznych, które mogą wspomóc poszukiwania, takich jak georadar ${ }^{16}, \operatorname{psy}^{17}$, sonar $^{18}$ czy drony ${ }^{19}$.

Zawsze warto wspierać się wiedzą biegłych, którzy wykonują badania w danych obszarach. Mogą to być badania psychologów polegające na stworzeniu portretu psychologicznego zaginionego, także z uwzględ-

16 M. Lisowicz, Nieinwazyjne metody poszukiwania zwłok ludzkich, [w:] Przypadki kryminalne. Poszukiwania osób zaginionych..., s. 34.

17 M. Lisowicz, Poszukiwanie zwłok ludzkich z użciem psa specjalistycznego w terenie otwartym, [w:] Przypadki kryminalne. Poszukiwania osób zaginionych..., s. 50.

18 M. Rokus, Powrót do nierozwiązanych spraw w działaniach Grupy Specjalnej Ptetwonurków RP, [w:] Przypadki kryminalne. Poszukiwania osób zaginionych..., s. 144.

19 M. Wojas, Drony w poszukiwaniach $i$ w ratownictwie, [w:] Przypadki kryminalne. Poszukiwania osób zaginionych..., s. 75. 
nieniem cech wiktymologicznych danej osoby, analiza danych z monitoringów, czy też badanie konkretnych zabezpieczonych śladów. Sprawy związane $\mathrm{z}$ analizą różnego rodzaju śladów nie są proste nawet $\mathrm{w}$ sytuacji, kiedy ciało osoby się odnajduje ${ }^{20}$. Tym bardziej należy podkreślić konieczność współpracy i wykorzystania wszystkich osiągnięć nauki dostępnych na dany moment - albo sprawdzenia za jakiś czas, czy nie pojawiła się nowa metoda, która pomogłaby rozwiązać stare sprawy.

Trzeba też pamiętać o tym, że zdarzają się wykrycia spraw przy prowadzeniu innych, pozornie niepowiązanych, spraw kryminalnych. Ślady zostają ujawnione niemalże przypadkiem, ale pozwalają na zamknięcie sprawy. Mogą to być zarówno ślady materialne, jak i niespodziewane zeznania czy wyjaśnienia osób. Nigdy nie można z góry przekreślić możliwości odnalezienia śladów przy danym zaginięciu. Są na pewno sprawy trudne, nawet bardzo trudne, ale nie ma nierozwiązywalnych.

Analizując różnego rodzaju zaginięcia z perspektywy zaginięć kryminalnych, nie sposób nie wspomnieć o zabójstwie Oetziego, tzw. Człowieka Lodu, znalezionego na pograniczu Austrii i Włoch. Ciało tego człowieka, który zapewne był zaginionym, spoczywało w lodzie przez ponad pięć tysięcy lat. Nie został pogrzebany, po upadku spowodowanym poniesioną raną upadł, a jego ciało pokrył śnieg i lód. Zapewne były osoby, które na niego czekały i nigdy nie poznały jego losów. Możemy poznać je my, wiele lat później. Wiemy, co i kiedy jadł przed śmiercią, jakich doznał obrażeń, na co chorował, w co był ubrany i jakie miał tatuaże. Jeśli po tylu latach udało się ujawnić, zabezpieczyć i zbadać tyle śladów, oczywiście w interdyscyplinarnych zespołach, to tym bardziej jest to możliwe w przypadkach zaginięć sprzed kilkunastu czy kilkudziesięciu lat.

\section{Bibliografia}

Diller R., Puzio-Broda M., ,,Minat już tydzień odkąd zaginęła twoja matka (...)”- historie wymagające wyjaśnienia, czyli nierozwiązane sprawy zaginięć osób, [w:] Przypadki kryminalne. Ciemna liczba przestępstw jako problem interdyscyplinarny, red. J. Stojer-Polańska, Poznań 2019.

20 J. Stojer-Polańska, M. Lisowicz, Czyja to czaszka, czyli o metodach identyfikacji zwłok, [w:] Przypadki kryminalne. Poszukiwania osób zaginionych..., s. 80. 
Górecki M., Ciemna liczba przestępstw — zaginięcie osoby, [w:] Przypadki kryminalne. Poszukiwania osób zaginionych jako problem interdyscyplinarny, red. J. Stojer-Polańska, Poznań 2018.

Kaczan S., Zaginięcia kryminalne, [w:] Przypadki kryminalne. Wspótpraca interdyscyplinarna przy badaniu ciemnej liczby przestępstw, red. J. Stojer-Polańska, Poznań 2016.

Lisowicz M., Nieinwazyjne metody poszukiwania zwłok ludzkich, [w:] Przypadki kryminalne. Poszukiwania osób zaginionych jako problem interdyscyplinarny, red. J. Stojer-Polańska, Poznań 2018.

Lisowicz M., Poszukiwanie zwłok ludzkich z użyciem psa specjalistycznego w terenie otwartym, [w:] Przypadki kryminalne. Poszukiwania osób zaginionych jako problem interdyscyplinarny, red. J. Stojer-Polańska, Poznań 2018.

Litka P., Michalec B., Nowak M., Polskie Archiwum X, Kraków 2016.

Litka P., Michalec B., Nowak M., Polskie archiwum X. Nie ma zbrodni bez kary, Kraków 2018.

Michalec B., Piniewska-Róg D., Stojer-Polańska J., Czego oczy nie widzq...? Studium pewnego zaginięcia, [w:] Przypadki kryminalne. Ciemna liczba przestępstw przeciwko kobietom, red. J. Stojer-Polańska, Poznań 2019.

Mrozowski P., Złe żony i kochający mężowie - studium przypadków, [w:] Przypadki kryminalne. Ciemna liczba przestępstw przeciwko kobietom, red. J. Stojer-Polańska, Poznań 2019.

Rokus M., Powrót do nierozwiazanych spraw w działaniach Grupy Specjalnej Ptetwonurków RP, [w:] Przypadki kryminalne. Poszukiwania osób zaginionych jako problem interdyscyplinarny, red. J. Stojer-Polańska, Poznań 2018.

Sitek E., Nie ma spraw beznadziejnych, „Policja 997” 2017, nr 10-11.

Stojer-Polańska J. et al., Ślady osób zaginionych, [w:] Przypadki kryminalne. Wspótpraca interdyscyplinarna przy badaniu ciemnej liczby przestępstw, red. J. Stojer-Polańska, Poznań 2016.

Stojer-Polańska J., Lisowicz M., Czyja to czaszka, czyli o metodach identyfikacji zwłok, [w:] Przypadki kryminalne. Poszukiwania osób zaginionych jako problem interdyscyplinarny, red. J. Stojer-Polańska, Poznań 2018.

Stojer-Polańska J., Michalec B., Lisowicz M., „,To be or not to be”. Samobójstwo z perspektywy stużby w Archiwum X, [w:] Percepcja zachowań samobójczych. Między opiniami a doświadczeniami, red. K. Rosa, A. Czabański, Kraków 2014.

Tracz R., Kochać to nie znaczy zawsze to samo, czyli dwie dekady z życia psychopaty, [w:] Przypadki kryminalne. Ciemna liczba przestepstw przeciwko kobietom, red. J. Stojer-Polańska, Poznań 2019.

Wach E., Zbrodnie nieidealne, [w:] Przypadki kryminalne. Wspótpraca interdyscyplinarna przy badaniu ciemnej liczby przestęsstw, red. J. Stojer-Polańska, Poznań 2016.

Wentkowska A., Poszukiwania osób zaginionych. System i metody działania w procedurach stużb, Warszawa 2016.

Wojas M., Drony w poszukiwaniach i w ratownictwie, [w:] Przypadki kryminalne. Poszukiwania osób zaginionych jako problem interdyscyplinarny, red. J. Stojer-Polańska, Poznań 2018.

Nowa Kodyfikacja Prawa Karnego 56, 2020

(C) for this edition by CNS 


\section{Akty prawne}

Zarządzenie nr 48 Komendanta Głównego Policji z dnia 28 czerwca 2018 roku w sprawie prowadzenia przez Policję poszukiwania osoby zaginionej oraz postępowania w przypadku ujawnienia osoby o nieustalonej tożsamości lub znalezienia nieznanych zwłok oraz szczątków ludzkich, Dziennik Urzędowy Komendy Głównej Policji 2018, poz. 77 .

\section{Criminal disappearances: searching for traces after many years}

\section{Summary}

This article concerns the problem of criminal disappearances when the absence of a victim is caused by a criminal act conducted by an offender. The reasons of disappearance may be due to murder and this fact can occur after some years. Even after many years, it is possible to find forensic traces, work with witnesses and determine the motive for the crime.

Keywords: disappearance, searching for missing people, teamwork. 